\title{
PERSALINAN PADA USIA $\geq 35$ TAHUN \\ DI RSU PROF. Dr. R. D. KANDOU MANADO
}

\author{
${ }^{1}$ Meyclin Dameria Sibuea \\ ${ }^{2}$ Hermie M. M. Tendean \\ ${ }^{3}$ Freddy W. Wagey
}

\author{
Bagian Obstetri dan Ginekologi RSU Prof. Dr. R. D. Kandou Manado \\ Universitas Sam Ratulangi \\ Email: d_mhay@rocketmail.com
}

\begin{abstract}
Childbirth at age 35 years is not without risk. Labor harder and longer, and stillbirth are problems that can be encountered in pregnancy and childbirth at age 55 years. This study aims to find data on births by age $\geq 35$ years. This study was conducted in November 2012 using retrospective descriptive method. Data were collected from medical record, the book of parturition and also from the subpart of Perinatology Prof. Dr. R. D. Kandou Public Hospital Manado in Januari 1 - December 31, 2011 period. This study found 846 birth at age $\geq 35$ years from 4154 total births. Presentation of the fetus is most commonly found is the location of the fetal head 534 cases, while the type of labor that is most often done is spontaneously 413 cases. Birth weight is the most commonly found in the group weighing $2500-<4000$ grams 704 cases $(81.39 \%)$. Perinatal deaths still occur till now $\left(15.67^{\circ} \%\right.$ ). Every pregnant mother will birth at age $\geq 35$ years more often advised to come to the clinic for prenatal care. Moreover, it is needed a doctor who is experienced and competent in minimizing morbidity and mortality in an act of childbirth.
\end{abstract}

Keywords: Childbirth, age $\geq 35$ years, incident

\begin{abstract}
Abstrak: Persalinan pada usia $\geq 35$ tahun bukan tanpa risiko. Persalinan yang lebih sulit dan lama, serta bayi lahir mati merupakan masalah yang dapat ditemui di kehamilan dan persalinan pada usia $\geq 35$ tahun. Penelitian ini bertujuan untuk mengetahui data mengenai persalinan pada usia $\geq 35$ tahun. Penelitian ini dilakukan pada bulan November 2012 dengan menggunakan metode deskriptif retrospektif. Data dikumpulkan dari rekam medik, buku partus dan juga beberapa data dari sub bagian Perinatologi RSU Prof. Dr. R. D. Kandou Manado periode 01 Januari 2011 - 31 Desember 2011. Ditemukan 846 persalinan pada usiæ 35 tahun dari 4154 total persalinan. Presentasi janin yang paling banyak ditemukan adalah janin dengan letak kepala yaitu 534 kasus, sedangkan jenis persalinan yang paling sering dilakukan adalah dengan cara spontan yaitu 413 kasus. Berat badan lahir yang paling banyak ditemukan adalah bayi dengan kelompok berat $2500-<4000$ gram yaitu 704 kasus (81,39\%). Kematian perinatal masih terus terjadi sampai saat ini $\left(15,67^{\circ} \%\right.$ oo. Setiap ibu yang hamil dan bersalin pada usia $\geq 35$ tahun, disarankan untuk lebih sering berkunjung ke klinik untuk melakukan pemeriksaan kehamilan. Selain itu, dibutuhkan adanya dokter yang berpengalaman dan berkompeten dalam meminimalkan tingkat morbiditas dan mortalitas dalam suatu tindakan persalinan.
\end{abstract}

Kata kunci: Persalinan, usia $\geq 35$ tahun, insidensi

Fenomena hamil di usia pertengahan (30 tahun) atau bahkan lebih tua bukan tanpa risiko dan mitos. Banyak orang percaya bahwa kehamilan yang terlambat (usia di atas 30 tahun) cenderung berisiko, tidak sehat dan penuh dengan komplikasi. Tapi hal itu tidak selamanya benar. Konsultan kesehatan kandungan dan kebidanan di Moolchand Fertility \& IVF New Delhi India, Dr. Shweta Gupta, mengatakan 
bahwa kehamilan yang terlambat tidak selamanya buruk dan berisiko bagi perempuan. ${ }^{1}$

Dalam beberapa tahun terakhir, pasangan di negara-negara industri memilih untuk menunda perkawinan dan melahirkan anak. ${ }^{2}$ Di Kanada, proporsi kelahiran pertama yang terjadi di kalangan wanita berusia $>30$ telah meningkat dalam 20 tahun terakhir. Dan saat ini, 11\% kelahiran pertama terjadi pada wanita berusia 35 tahun. Tren untuk menunda hamil dan melahirkan anak juga terjadi di Eropa Barat, Australia, Selandia Baru, dan Amerika Serikat. ${ }^{3}$ Di negara maju seperti Finlandia, pada tahun 1997, 8,3\% dari primigravida merupakan wanita dengan usia di atas 35 tahun. Pada tahun 2007, ini meningkat menjadi $10,4 \%$. Situasi ini sangat sebanding dengan Swedia, dimana pada tahun 2007, 10\% dari primigravida berusia 35 tahun atau lebih tua. ${ }^{4}$ Pada penelitian di RSUP Manado 2001-2002, didapatkan 4630 persalinan, diantaranya 686 kehamilan pada usia 35 tahun atau lebih (14,81\%). Jumlah ini cenderung meningkat dari 305 tahun 2001 (2353 kehamilan) menjadi 381 dari 277 kehamilan di tahun 2002. ${ }^{5}$

Kehamilan adalah masa yang menggembirakan. Di zaman sekarang ini, makin banyak wanita yang berbahagia ketika mengetahui mereka hamil pada usia 30-40 tahunan. Hal ini mungkin disebabkan oleh karena semakin berkembangnya bidang pendidikan dan lapangan pekerjaan bagi kaum wanita sehingga lebih banyak wanita yang terlambat menikah bahkan menunda untuk mempunyai anak sampai karier mereka pasti atau hubungan mereka terbina dengan kuat. ${ }^{6,7,8}$

Pendidikan dan pendapatan merupakan kunci penentu kesehatan. Ada implikasi kesehatan positif untuk wanita yang memiliki pendidikan dan pendapatan lebih tinggi, dimana mereka mungkin memiliki lebih banyak kemampuan untuk mendukung pertumbuhan (kebutuhan hidup) keluarga, terutama anak-anak mereka. ${ }^{1}$ Setiap hari di Amerika Serikat, hampir 200 orang wanita yang berusia 35 tahun atau lebih tua melahirkan bayi pertama mereka. ${ }^{6,9}$ Dilihat dari kondisi psikologis dan mentalnya, wanita usia 30-an lebih siap menjadi seorang ibu. Namun ada pula beberapa tantangannya. Terkait dengan kondisi kesehatan yang menurun, maka kualitas sel telur pun akan menurun sehingga dapat meningkatkan risiko keguguran, serta kelainan/ cacat bawaan pada janin akibat kelainan kromosom. Selain itu, mulai muncul berbagai keluhan kesehatan saat hamil, seperti; tekanan darah tinggi dan diabetes yang sering memengaruhi proses persalinan.,10 Faktor-faktor inilah yang menyebabkan persalinan di usia 30-an cenderung lebih sering dilakukan melalui operasi caesar. ${ }^{6}$

Kehamilan risiko tinggi adalah kehamilan yang dapat menyebabkan ibu hamil dan bayi menjadi sakit dan/ atau meninggal sebelum persalinan berlangsung. ${ }^{6}$ Bayi meninggal atau cacat, bahkan ibu meninggal saat persalinan sering terjadi pada kehamilan usia 35 tahun ke atas. ${ }^{11}$ Banyak faktor risiko ibu hamil dan salah satu faktor yang penting adalah usia. Ibu hamil pada usia lebih dari 35 tahun lebih berisiko tinggi untuk hamil dibandingkan bila hamil pada usia normal, yang biasanya terjadi sekitar 21-30 tahun. ${ }^{6}$ Menurut dr. Damar Prasmusinto, SpOG (K), melahirkan di usia 35 tahun ke atas, bayi yang dilahirkan rentan mengalami kelainan genetik. Pada usia reproduktif (25-35 tahun), risiko bayi alami kelainan genetik 1:1000, sedangkan pada ibu yang berusia di atas 35 tahun, risiko itu meningkat menjadi 1:4. Oleh karena itu, baiknya usia ibu untuk melahirkan berada pada rentang 25-35 tahun. ${ }^{12}$

Berdasarkan latar belakang masalah diatas, maka penulis tertarik untuk meneliti gambaran Persalinan Pada Usia $\geq 35$ Tahun Di RSU Prof. Dr. R. D. Kandou Manado.”

\section{METODE}

Penelitian ini bersifat deskriptif retrospektif dengan mengkaji data dari rekam medik, buku partus di kamar bersalin di bagian Obstetri dan Ginekologi dan juga beberapa data dari sub bagian Perinatologi.

Penelitian ini dilakukan pada bulan November 2012 dengan subyek penelitian yaitu seluruh ibu yang melahirkan pada usia $\geq 35$ tahun di bagian Obstetri dan Ginekologi 
RSU Prof. Dr. R. D. Kandou Manado periode 1 Januari - 31 Desember 2011. Variabel yang diteliti adalah insiden, paritas, usia kehamilan, jenis presentasi, jenis persalinan, berat badan lahir, kematian perinatal dan luaran maternal.

Data pada penelitian ini diolah dengan menggunakan Microsoft Office Excel 2007, kemudian disajikan dalam bentuk tulisan, tabel dan gambar.

\section{HASIL}

Tabel 1. Insiden persalinan pada usia $\geq 35$ tahun

\begin{tabular}{lccc}
\hline Tahun & $\begin{array}{c}\text { Jumlah } \\
\text { Persalinan }\end{array}$ & $\begin{array}{c}\text { Jumlah } \\
\text { persalinan } \\
\text { pada usia } \geq \\
\text { 35 tahun }\end{array}$ & \% \\
\hline 2011 & 4155 & 846 & 20,36 \\
\hline
\end{tabular}

Selama periode 1 Januari - 31 Desember 2011 didapatkan 4155 kasus persalinan. Jumlah persalinan pada usia $\geq 35$ tahun yaitu 846 kasus (20,36\%), yang terdiri dari 19 kasus kelahiran kembar (gemelli) dan 827 kasus kelahiran tunggal.

Tabel 2. Insiden persalinan pada usia $\geq 35$ tahun menurut paritas

\begin{tabular}{lcc}
\hline \multirow{2}{*}{ Paritas } & \multicolumn{2}{c}{ Tahun $\mathbf{2 0 1 1}$} \\
\cline { 2 - 3 } & Jumlah & $\mathbf{\%}$ \\
\hline P 0 & 88 & 10,40 \\
P $1-3$ & 642 & 75,89 \\
P $\geq 4$ & 116 & 13,71 \\
Total & $\mathbf{8 4 6}$ & $\mathbf{1 0 0}$ \\
\hline
\end{tabular}

Tabel 2 memperlihatkan insiden persalinan pada usia $\geq 35$ tahun berdasarkan paritas, dimana yang paling banyak ditemukan yaitu pada paritas 1-3, sebanyak 642 kasus (75,89\%).

Tabel 3 memperlihatkan bahwa persalinan pada usia $\geq 35$ tahun banyak terjadi pada kelompok dengan usia kehamilan 37 - 40 minggu 681 kasus (80,50\%).
Tabel 3. Distribusi persalinan pada usia 35 tahun menurut usia kehamilan

\begin{tabular}{lcc}
\hline \multirow{2}{*}{$\begin{array}{c}\text { Usia } \\
\text { Kehamilan }\end{array}$} & \multicolumn{2}{c}{ Tahun $\mathbf{2 0 1 1}$} \\
\cline { 2 - 3 } & Jumlah & $\mathbf{\%}$ \\
\hline$\leq 36$ minggu & 74 & 8,75 \\
$37-40$ minggu & 681 & 80,50 \\
$\geq 41$ minggu & 91 & 10,75 \\
Total & $\mathbf{8 4 6}$ & $\mathbf{1 0 0}$ \\
\hline
\end{tabular}

Tabel 4. Distribusi persalinan pada usia 35 tahun menurut jenis presentasi

\begin{tabular}{lcc}
\hline \multirow{2}{*}{ Jenis Presentasi } & \multicolumn{2}{c}{ Tahun 2011} \\
\cline { 2 - 3 } & Jumlah & $\mathbf{\%}$ \\
\hline Letak kepala & 534 & 61,74 \\
Letak sungsang & 170 & 19,65 \\
Letak lintang & 68 & 7,86 \\
Tidak diketahui & 93 & 10,75 \\
Total & $\mathbf{8 6 5}$ & $\mathbf{1 0 0}$ \\
\hline
\end{tabular}

Tabel 4 memperlihatkan presentasi janin yang paling banyak ditemukan yaitu janin dengan letak kepala 534 kasus (61,74\%).

Tabel 5. Distribusi persalinan pada usia 35 tahun menurut jenis persalinan

\begin{tabular}{lcc}
\hline \multirow{2}{*}{ Jenis Persalinan } & \multicolumn{2}{c}{ Tahun 2011} \\
\cline { 2 - 3 } & Jumlah & $\mathbf{\%}$ \\
\hline Spontan & 413 & 48,82 \\
Seksio Sesarea & 390 & 46,81 \\
Ekstraksi Vakum & 27 & 3,19 \\
Ekstraksi Forcep & 2 & 0,24 \\
Ekstraksi Parsial & 8 & 0,94 \\
Total & $\mathbf{8 4 6}$ & $\mathbf{1 0 0}$ \\
\hline
\end{tabular}

Pada Tabel 5, jenis persalinan yang paling sering dilakukan pada usia $\geq 35$ tahun adalah jenis persalinan dengan cara spontan sebanyak 413 kasus (48,82\%).

Tabel 6 memperlihatkan berat badan lahir yang paling banyak ditemui yakni bayi dengan kelompok berat $2500-<4000$ gram 704 kasus (81,39\%). 
Tabel 6. Distribusi persalinan pada usi 35 tahun menurut berat badan lahir

\begin{tabular}{lcc}
\hline \multirow{2}{*}{$\begin{array}{c}\text { Berat Badan } \\
\text { Lahir } \\
\text { (gram) }\end{array}$} & \multicolumn{2}{c}{ Tahun 2011 } \\
\cline { 2 - 3 }$<2500$ & Jumlah & $\mathbf{\%}$ \\
\hline $2500-<4000$ & 108 & 12,48 \\
$\geq 4000$ & 704 & 81,39 \\
Total & 53 & 6,13 \\
\hline
\end{tabular}

Tabel 7. Distribusi kematian perinatal pada persalinan usia $\geq 35$ tahun

\begin{tabular}{cccccc}
\hline Tahun & JLH & LM & KND & KP & $\begin{array}{c}\text { AKP } \\
(\mathbf{0} \%)\end{array}$ \\
\hline 2011 & 4007 & 48 & 16 & 64 & 15,97 \\
\hline
\end{tabular}

Ket: JLH = Jumlah Lahir Hidup; LM = Lahir Mati; KND $=$ Kematian Neonatal Dini; KP = Kematian Perinatal; AKP = Angka Kematian Perinatal

Pada tabel 7 dapat dilihat bahwa kematian perinatal pada tahun 2011 adalah sebanyak 64 kasus $\left(15,97^{\circ} \%\right.$ оo).

Tabel 8. Distribusi luaran maternal pada persalinan usia $\geq 35$ tahun

\begin{tabular}{lcc}
\hline \multirow{2}{*}{ Luaran Maternal } & \multicolumn{2}{c}{ Tahun 2011} \\
\cline { 2 - 3 } & Jumlah & $\mathbf{\%}$ \\
\hline Luaran Hidup & 845 & 99,89 \\
Luaran Meninggal & 1 & 0,11 \\
Total & $\mathbf{8 4 6}$ & $\mathbf{1 0 0}$ \\
\hline
\end{tabular}

Pada tabel 8 dapat dilihat bahwa jumlah kematian maternal pada usia $\geq 35$ tahun di tahun 2011 sebanyak 1 kasus $(0,11 \%)$.

\section{BAHASAN}

Pada penelitian ini diperoleh jumlah persalinan tahun 2011 yaitu sebanyak 4155 kasus persalinan. Pada usita 35 tahun diperoleh 846 kasus (20,36\%). Jumlah ini mengalami peningkatan sebesar \pm 2 kali lipat jika dibandingkan dengan penelitian yang dilakukan pada tahun 2010 di RSU Prof. Dr. R. D. Kandou Manado dan RSUP Dr. M.
Jamil Padang. Pada penelitian yang dilakukan di RSU Prof. Dr. R. D. Kandou Manado jumlah persalinan tahun 2010 adalah sebanyak 2612 kasus persalinan. ${ }^{13}$ Dan pada penelitian yang dilakukan di RSUP Dr. M. Jamil Padang diperoleh sebanyak 346 kasus persalinan (12,3\%) pada usia $\geq 35$ tahun dari total 2810 kasus persalinan. $^{14}$

Dari segi paritas, pada tabel 2 dapat dilihat bahwa pada usia $\geq 35$ tahun yang terbanyak adalah pada paritas 1-3, yaitu sebanyak 642 kasus (75,89\%) dan paling sedikit pada paritas 0 (nol), yaitu sebanyak 88 kasus (10,40\%).

Kelompok usia kehamilan yang paling banyak ditemukan pada penelitian ini adalah kelompok dengan usia kehamilan 37 - 40 minggu, yaitu 681 kasus (80,50\%) dan yang paling sedikit pada kelompok dengan usia kehamilan $\leq 36$ minggu 74 kasus $(8,75 \%)$. Hasil dari penelitian ini menunjukkan bahwa kebanyakan wanita yang bersalin pada usia $\geq 35$ tahun berada dalam rentang waktu kehamilan yang normal, yaitu 37 - 40 minggu.

Presentasi janin yang paling banyak ditemukan pada persalinan dengan usia $\geq 35$ tahun, yaitu janin dengan letak kepala 534 kasus $(61,74 \%)$ dan yang paling sedikit yaitu janin dengan letak lintang 68 kasus (7,86\%). Pada penelitian primigravida tua yang bersalin di RSU Prof. Dr. R. D. Kandou Manado tahun 1997-2001 juga didapatkan bahwa janin umumnya letak kepala (90\%), sungsang (14\%), letak lintang $(2 \%)^{5}$

Terdapat 5 jenis persalinan, yaitu spontan, seksio sesarea, ekstraksi vakum, ekstraksi forcep, dan ekstraksi parsial. Dan dari tabel tersebut diperoleh jenis persalinan yang paling sering dilakukan tahun 2011 pada persalinan dengan ușa 35 tahun adalah jenis persalinan dengan cara spontan, yakni sebanyak 413 kasus (48,82\%), sedangkan jenis persalinan lainnya seperti seperti seksio sesarea sebanyak 396 kasus (46,81\%), ekstraksi vakum sebanyak 27 kasus (3,19\%), ekstraksi forcep sebanyak 2 kasus (0,24\%), dan ekstraksi parsial sebanyak 8 kasus (0,94\%). Berdasarkan 
penelitian yang dilakukan di RSUP dr. M. Jamil Padang tahun 2010, didapatkan hasil yang serupa dimana persalinan pada usiạ 35 tahun paling banyak menggunakan jenis persalinan dengan cara spontan, yaitu sebanyak 205 kasus (59,2\%) sedangkan jenis persalinan dengan tindakan sebanyak 141 kasus (40,8\%). ${ }^{14}$

Menurut Sarwono, sampai sekarang etiologi berat badan lahir rendah belum cukup memuaskan, menurut besarnya penyebab kelahiran bayi dengan berat lahir rendah dapat dilihat dari faktor janin dan faktor ibu. Faktor janin meliputi kehamilan ganda dan hidramnion dimana keadaan air ketuban melebihi jumlah normal (2 liter). Sedangkan faktor ibu meliputi umur ibu, usia kehamilan, paritas, pemeriksaan kehamilan, status nutrisi dan penyakit yang diderita ibu. Setyowati juga mengatakan bahwa bayi dengan berat badan lahir rendah banyak terjadi pada ibu-ibu yang berumur kurang dari 20 tahun dan lebih dari 35 tahun. ${ }^{15}$ Pada tabel 6 dapat dilihat berat badan lahir yang paling banyak ditemukan pada persalinan dengan ușa 35 tahun adalah pada bayi dengan kelompok berat 2500 - <4000 gram yaitu sebanyak 704 kasus (81,39\%) sedangkan yang paling sedikit didapatkan pada bayi dengan kelompok berą 4000 gram 53 kasus (6,13\%). Namun, jumlah kasus berat badan lahir rendah ( $<2500$ gram) pada penelitian ini juga banyak, yaitu 108 kasus (12,48\%).

Angka kematian perinatal pada tahun 2011 adalah sebanyak 64 kasus $(15,97 \%$ oo), yang terdiri dari 48 kasus lahir mati dan 16 kasus kematian neonatal dini (KND). Usia ibu > 35 tahun berpengaruh terhadap kejadian kematian perinatal. Hal ini sesuai dengan teori yang menyatakan bahwa kehamilan diatas 35 tahun merupakan salah satu faktor risiko kematian perinatal karena kehamilan pada usia > 35 tahun lebih memungkinkan terjadinya keguguran, bayi lahir mati atau cacat, dan kematian ibu. Penelitian-penelitian sebelumnya juga memperlihatkan risiko untuk terjadi kematian neonatal pada ibu yang berusia < 20 tahun atau > 35 tahun, 1,5 kali lebih besar daripada ibu yang berusia 20-34 tahun. $^{16}$

Jumlah kematian maternal pada usia $\geq$ 35 tahun di tahun 2011 sebanyak 1 kasus $(0,11 \%)$. Kematian maternal meningkat seiring dengan bertambahnya usia ibu. ${ }^{3}$ Berdasarkan data/ informasi kesehatan Provinsi Sulawesi Utara, pada tahun 2007 terdapat 59 kasus kematian maternal, tahun 2008 menurun menjadi 50 kasus. Namun, kejadian ini meningkat pada tahun 2010 dimana terdapat 69 kasus kematian maternal. ${ }^{17,18}$

Penelitian ini memiliki kekurangan, dimana terdapat beberapa data yang tidak diketahui dikarenakan catatan rekam medik yang tidak lengkap. Kami pun tidak dapat memperoleh data dari petugas kesehatan yang terlibat dalam persalinan, dikarenakan penelitian ini bersifat retrospektif.

\section{SIMPULAN}

Setiap ibu yang hamil dan bersalin pada usia $\geq 35$ tahun, disarankan untuk lebih sering berkunjung ke klinik untuk melakukan pemeriksaan kehamilan. Selain itu, dibutuhkan adanya dokter yang berpengalaman dan berkompeten dalam menangani serta meminimalkan tingkat morbiditas dan mortalitas dalam suatu tindakan persalinan, terutama untuk masalah-masalah yang berkaitan dengan persalinan pada usia $\geq 35$ tahun.

\section{UCAPAN TERIMA KASIH}

Terima kasih kepada dr. Rudy A. Lengkong, SpOG-K dan dr. Juneke J. Kaeng, SpOG-K yang telah memberikan saran/ masukan yang sangat bermanfaat dalam penyelesaian penelitian ini. Dan juga tak lupa kepada semua pihak yang secara langsung atau pun tidak langsung telah menumbuhkan gagasan dalam artikel ini.

\section{DAFTAR PUSTAKA}

1. Mikail B. Hamil di Usia 30 Tahun Tak Selamanya Berisiko. 2012 [diakses tanggal 16 Okt 2012]. Diunduh dari: http://health.kompas.com/read/ 2012/02/29/11380796/Hamil.di.Usia.30.Tah un.tak.Selamanya.Berisiko 
2. Aghamohammadi A, Nooritajer $\mathbf{M}$. Maternal Age As a Risk Factor For Pregnancy Outcomes: Maternal, Fetal and Neonatal Complication. Afr J Pharm Pharmacol. 2011; 5(2):264.

3. Johnson A, Tough S. Delayed ChildBearing. J Obstet Gynaecol Can. 2012;34 (1):81.

4. Lampinen $\mathbf{R}$, Vehviläinen $\mathbf{K}$, Kankkunen $\mathrm{P}$, et al. A Review of Pregnancy in Women Over 35 Years of Age. The Open Nursing Journal. 2009;3:33.

5. Masengi GA. Perbandingan Kejadian Penyulit Persalinan Pada Primigravida Tua Dengan Primigravida Usia Reproduksi Sehat di RSUP Prof. Dr. R. D. Kandou Manado Periode 2007-2009 [Skripsi]. Jakarta: Universitas Pembangunan Nasional Veteran; 2011.

6. Curtis GB. Kehamilan di Atas Usia 30. Dalam: Satyanegara S (editor), Asih Y (alih bahasa). Jakarta: Arcan; 1999.

7. Hanif HM. Association Between Maternal Age and Pregnancy Outcome: Implications for The Pakistani Society. Journal of the Pakistan Medical Association. 2011;61(3): 313.

8. Ates S, Batmaz G, Sevket O, Molla T, Dane C, Dane B. Pregnancy Outcome of Multiparous Women Aged over 40 Years. International Journal of Reproductive Medicine. 2013:1,3.

9. Tribun Manado. Haruskah Takut Melahirkan di Atas Usia 35? 2011 [diakses tanggal 21 Okt 2012]. Diunduh dari: http://manado.tribunnews.com/2011/05/04/h aruskah-takut-melahirkan-di-atas-usia-35

10. Hamil Sukses dan Prima di Usia 30-an. [diakses tanggal 20 Okt 2012]. Diunduh dari:http://www.ayahbunda.co.id/Artikel/ke hamilan/gizi+dan+kesehatan/hamil.sukses.d an.prima.di.usia.30an/001/001/924/41/2

11. Sinsin I. Seri Kesehatan Ibu dan Anak Masa Kehamilan dan Persalinan. Jakarta: PT. Elex Media Komputindo, 2008; p.61.

12. Natali G. Melahirkan di Atas Usia 40 Cegah Kanker Rahim. 2008 [diakses tanggal 16 Okt 2012]. Diunduh dari: http:// preventionindonesia.com/article.php?name= /melahirkan-di-atas-usia-40-cegah-kankerrahim\&channel=health\%2Fhealthy_ lifestyle

13. Tuange A. Profil Persalinan Kehamilan Kembar di BLU RSU Prof. Dr. R. D. Kandou Manado Periode 01 Januari - 31 Desember 2011 [skripsi]. Manado: Universitas Sam Ratulangi; 2011.

14. Yusrawati, Asviandri, Sulin D. Hasil Kehamilan Pada Usis di Atas dan sama dengan 35 Tahun [skripsi]. Padang: Universitas Andalas; 2010.

15. Oktavilesia D. Faktor-Faktor Yang Berhubungan Dengan Kejadian Berat Badan Lahir Rendah di RSUD Arifin Achmad Pekanbaru Tahun 2008 [Skripsi]. Padang: Universitas Andalas; 2011.

16. Wantania J, Wilar R, Antolis $Y$, Mamangkey G. Faktor Risiko Kehamilan Dan Persalinan Yang Berhubungan Dengan Kematian Neonatal di RSU Prof. R. D. Kandou Manado. Jakarta: PERINASIA; 2011; (3). Hal 3.

17. Data/Informasi Kesehatan Provinsi Sulawesi Utara. 2010 [diakses tanggal 5 Januari 2013]. Diunduh dari: http://www.depkes.go. id/downloads/kunker/24_sulut.pdf

18. Profil Kesehatan Sulawesi Utara Tahun 2008. 2009 [diakses tanggal 5 Januari 2013]. Diunduh dari: http://www.depkes.go.id/downloads/profil/p rov_sulut_2008.pdf 